\title{
The Mechanisms of Civil Society Organization and the Relation of Social Peace among University Students
}

\author{
Mervat G. Shamroukh (Ph.D.) \\ Kareem H. Hammam (Ph.D.) \\ Department of Community Organization \\ Faculty of Social Work, Helwan University
}




\title{
The Mechanisms of Civil Society Organization and the Relation of Social Peace among University Students
}

\author{
Mervat G. Shamroukh (Ph.D.) \\ Kareem H. Hammam (Ph.D.) \\ Department of Community Organization
}

Faculty of Social Work, Helwan University

\section{ABSTRACT:}

The research describes "social dialogue" as one of the mechanisms used by civil society organizations in Egypt, especially non-governmental organizations, for creating a culture of social peace among university youth, for the purpose of combating intellectual deviation and achieving development goals. Intellectual deviation, and resulting destruction, corruption of minds, and exhaustion of lives, has become a threatening phenomenon to societies in general, and the Egyptian society in particular. In light of the recent rise in intellectual deviation and promotion of corrupt and inhumane principles, using social dialogue to address this deviation has become a necessity.

The philosophy of social dialogue is based on the establishment and strengthening of societal values, assets, and ethics, and on social justice. The culture of social peace advocates for respecting opinions and positive dialogue between community sectors. One of the principle research questions was what are the mechanisms used by nongovernmental organizations for realizing social peace values. This question could be answered through social dialogue.

The research asserted the importance of the role played by non-governmental organizations in realizing social peace through social dialogue.

\section{KEYWORDS:}

Social Peace - Mechanisms of Civil Society Organizations - Social Dialogue

\section{INTRODUCTION:}

Social peace is a human need. Its presence in a society and the prevalence of its values create an environment that encourages progress and development. The rise in violence and aggressive demonstrations over the past few years reflect a weakness in social 
peace culture, and call attention towards other underlying societal ailments that need to be addressed.

Social peace requires establishing right relationships with others. In living social peace, we are responsible to examine how we manage our interpersonal conflicts and differences. We practice social peace through dialogue, especially social dialogue in the current reality (Kerissen, 2013).

In addition, the internet has become a tangible reality in our contemporary life. With its introduction, new virtual worlds have formed (Holt, 2012). Social media accounts for as much as one third of new web content. That is why it has gained considerable interest by corporations, governments, and non-governmental organization (Finin, Joshi, Karandi Kar, 2008.p.p 77-92). As more of our world moved into online spaces, special media platforms become a central fountainhead for dispersed communities to share innovative ideas (Peppler, Solomou, 2011, pp. 13-23).

Peace as a cultural value is associated with proper application of social justice. Therefore, spreading and supporting a culture of social justice remains a challenge that can be addressed through reasoning, diligence, and openness to all that is new. Deliberate rooting and purposive modernization contribute to spreading the culture of social justice (El Azab, 2002, p. 372).

A conformity exists between the values of social justice and social work philosophy, which promotes justice and equality, and aims for peace to become the language and culture of individuals, the right of peoples, and the dream of humanity.

A study by Allen Judd indicated that understanding the culture of minorities and the concept of a comprehensive culture that helps develop the capacities of young people is derived from realizing internal peace between individuals, peace between organizations, and world peace (Judd, 1989, p. 1-9). The culture of peace consists of values, attitudes, and behaviors that reject violence in a peaceful world. We solve problems through dialogues and negotiations (David Adams, Michael, 1997).

Hence, the main elements for realizing peace and social security in society are as follows:

1. Security and social peace

3. Clean environment
2. Social action

4. Informational and cultural services. 
5. Suitable housing.

7. Educational services.
6. Job opportunities

8. Health services (Afifi,2002,pp. 256257)

In order to progress, civil society has to provide effective mechanisms that go beyond informing decision makers of public opinion to employing specialized methods, starting with the formation of non-governmental organizations, to analyzing youth related issues, while responsibly representing the public opinion (UNDP, 1992, p. 129).

Hence, we find that in most societies, NGOs supplement the efforts of the public and private sectors. They are considered more professional, faster, and more flexible in addressing existing problems and future challenges.

In a study by Doubilet, she stressed the value of participation in developing the culture of peace, focusing on the attitudes and behaviors of young people, supporting peace education, and spreading values of democracy and respect among community members (Karen Doubilet, 2007).

Youth in any State are considered human power that possess the capacities to effect development and influence change. Our youth, however, suffer from a cultural and intellectual vacuum that allowed for the entry of extremist ideas and negative behavior, which could be threatening for the stability of any State. Thus, we have to turn towards the positive values that form the basis of peace culture for elevating young people's ideologies and for protecting them against moral and hostile ideologies.

Because of the dangers posed by hostile and destructive ideologies, the diversity of their sources and methods, and the seriousness of their effects, it was necessary for states and societies to put in place strategies for facing them. Such strategies primarily depend on the concerted efforts of individuals and organizations from all levels of society (Alaa, 2002). For example, Saudi Arabia has implemented a strategy for combating electronic terrorism through awareness. This included training programs for all sectors, especially university students, to promote tolerance and reject violence. Similarly, Morocco has adopted a strategy for promoting peace and combating extremist ideology.( Report 2016) 
While we are working to resist radical ideology, we note the presence of individual and collective cultural deviations that is manifested in the form of organizations or groups where such ideologies are spread. Despite the dangers that collective cultural deviation poses, a high risk lies in individual deviation, where an individual could join other existing groups or form new groups that support said ideology. In both cases, resisting cultural deviation, reforming societal culture and purifying it of problematic ideologies are done in four stages (Amnaa, 2002)

\section{Preventive Stage:}

This is the stage where responsible entities take precautions to prevent the occurrence of deviation. All entities within a State participate with security services in this stage.

\section{Discussion and Social Dialogue Stage:}

When the preventive stage is not sufficient, some destructive ideas, which may be imported, begin to rise. The growth of such ideas depends on the vigilance of security services and their precautionary procedures. It is also the role of religious leaders, thinkers, and experts, especially in media and research centers, to confront those ideas once they emerge through using discussion, presenting facts, and refraining from violence. In this stage, civil society organizations, especially NGOs, have the principle role in maintaining constructive dialogue and ensuring the credibility of facts, provided a balance of power exists between all parties, and that they agree to participate willingly.

\section{Mending Stage:}

The seriousness of ideological deviation among a group or individual youth may render dialogue and discussion futile, especially if the facilitator fails to convince them, or if their ideas hold some logic. In this case, other activities are planned and implemented to provide youth with facts and positive ideas like camps and field visits.

\section{Law Enforcement Stage:}

When the previous stages fail, relevant authorities realize the danger of such intellectual deviances, resulting the enforcement of applicable laws.

The researchers recognizes that social dialogue, if applied properly, is an important mechanism that could result in securing youth's cultural and intellectual environment. Social dialogue and related interactions 
are major tools for controlling the collective action of an organization, group, or individual youth through the rationalization of their decision. Social dialogue also ensures the organization or group's continuity, and the sustainability of its functions.

One of the studies asserted that dialogue helps identify social issues and design strategies for improving local services and available opportunities for community members.Dialogue is a necessity to effect change in organizations and in society, because it raises the awareness of the social dialogue participants (Karen J; Mostade, Jeffrey, 2004).

In addition, social dialogue helps build the capacities of youth to cope with globalization changes on the local and international levels. It also contributes to the activation of the role of youth in political parties (El Amry, 2007). This is done through the activities and volunteering initiatives implemented by NGOs after their involvement in peace efforts as indicated in Kropiunig's study that affirmed the necessity for self-support and for reducing negative ideas affecting youth in the field of peace and development. Situational changes in society have to be made in order to spread the values and culture of peace.

Hence, NGOs are currently receiving considerable attention because of the significance of their joint action with other sectors (Saad, 2000, p. 22). NGOs have become the mainstay for safeguarding the social and civil structure (Nabil, 2000, p. 3).

The study by Chapman Thomas explained that social dialogue had a positive impact in addressing the disputes prevailing in three communities in Florida in 2002. Analysis of discussions and social dialogues implemented in the three communities concluded that social dialogue processes were successful in affirming the protection of minority rights against discrimination and protection of human rights for people of all races as per citizenship related conventions (Chapman Thomas E, 2009).

The study by Laura West reaffirmed the importance of Facebook discussions as a new element for exploring the complexity of face-toface discussions and the participation in social dialogue using the computer. The study tackled the effect of dialogue through Facebook on the upbringing of persons of a specific generation. It provided evidence that persons connected on Facebook around the world use 
texts derived from local languages in an attempt to find common communication media for presenting themselves to others (West, Laura E, 2010).

Hence, NGOs have a role in developing the culture of social peace among youth through applying social dialogue. If the existence of NGOs is an indicator of democracy, the lack of democracy necessarily requires the presence of civil organizations working to build a democratic society. Thus, the mere existence of NGOs does not reflect democracy, but rather their activation is considered one of mechanisms for applying democracy (Lan M. Harris, Marlee, 2008 pp.128-129,).

The relationship between youth and NGOs can be viewed on two levels. The first level is youth participation in the activities and programs implemented by the NGOS. The second level is the effective participation of youth in the NGO's work.

Hence emerges the role of organizations in training and education for promoting peace culture through effective social dialogue. NGOs recognize young people's reluctance for political and social participation due to poor conditions that left them frustrated. They also recognize the importance of dialogue as the core of social peace process (values of social communication, freedom, and accepting differences). Thus, there is a need for coordination between actors and networks working towards peace to engage youth effectively through community dialogue (Asaad, 2001).

Community organization appears to face a huge task in developing communities due to the complexity and interconnectivity of their problems (Rashad Ahmed, 2005, 0.12).

As per the above, using social dialogue in promoting the culture of social peace within NGOs has become a necessary and vital process for mobilizing developing communities towards a more advanced status.

\section{Theoretical Guidelines of the Research:}

Social Control Theory: The theory helps understand the behavior of individuals, their acceptance or rejection of social peace culture, and the NGOs' application of social dialogue for transforming negative values among individuals to positive values.

Organizations Theory: The theory helps analyze organizations from a social work perspective, focusing on understanding the nature 
and goals of an organization, and identifying the main problems that face the organization and methods for addressing them. This is in addition to making use of the theory as a tool for influencing individuals in organizations and society, and directing them towards positivity.

\section{Research Goals:}

1- Identifying the requirements of social dialogue as a mechanism used by nongovernmental organization with youth for the realization of social peace.

2- Identifying the efforts of nongovernmental organizations in spreading the sense of belonging and amiability between youth for the realization of social peace.

3- Identifying the obstacles facing nongovernmental organizations in the realization of social peace using social dialogue.

\section{The Questions:}

1- What are the mechanisms used by nongovernmental organizations for realizing social peace? This question can be answered through social dialogue.

2- What efforts are exerted by nongovernmental organizations to spread the culture of social peace? This question can be answered through the indicators: belonging, amiability, justice, and tolerance.

3- What obstacles do the nongovernmental organizations face in realizing social peace through social dialogue?

\section{Concepts:}

Social Peace: Peace is a state of harmony, compatibility, and lack of enmity between two parties. It means resolution and reconciliation, and it is the main message of divine religions. Peace is an indication of the human right to survive and the elevation of humanity over brutality. It is a way to steer people's efforts towards assistance and prosperity, to ensure economic, political, and social security for people (Ibrahim Madkour 1979, p517).

\section{The operation definition of Social Peace in this study are:}

1. Belonging: meaning the youth's feeling towards their homeland, the sense of belonging to the country, and the desire for creating positive change. Measuring through the questionnaire in the study. 
2. Tolerance: meaning youth's belief that work helps them achieve their hopes and ambitions, and their satisfaction with what they are given.

\section{. Civil Society Organizations Mechanisms:}

'Mechanism' linguistically means aggregation of parts in a machine (Mounir, 1995 p.56). In previous studies, this term was substituted with 'method' or 'tool' (dictionary, 1983, p. 917).

In this research, we mean by 'mechanisms' the methods which nongovernmental use to spread the culture of social peace, and the social dialogue performed with youth.

\section{Social dialogue:}

Webster defined 'dialogue' as "conversation or discussion between two or more persons, or the attempt to reach an agreement between two or more persons democratically through exchange in views and ideas" (Marginson P, 2006,p.50).

Yehl Miao indicated that social dialogue is a process of building trust and reaching consensus between conversing parties based on a clarity of shared values and triggering a desire for joint action (Yehi Miao, 2004).

\section{The operation definition of Social dialogue in this study are:}

1- Social dialogue is a development activity aiming to support the participation of youth and nongovernmental organizations in realizing social peace.

2- Social dialogue endeavors to spread tolerance, freedom or opinion, and respect for the views of the different parties.

3- Social dialogue is a mechanism for continual improvement of internal relations between community members, social organization, and its internal units.

\section{METHODOLOGY}

Type: This research is considered a descriptive research that seeks to identify the characteristics of a specific problem and examine its surrounding conditions

The research used the social survey method, which gathers social data through codified interviews or codified research questionnaires (Gohary, 1995. p. 100).

A comprehensive social survey was implemented with board members of nongovernmental organizations and a sample of beneficiaries. 


\section{Tools:}

A. Questionnaire used with board members, staff, and social workers on realizing social peace among youth through social dialogue.

The following steps were followed in designing the tool:

The tool was initially built on the theoretical framework of the study and relevant previous studies. The tool was then presented to twelve faculty members at the Faculty of Social Work, Helwan University for review. The tool was approved by the faculty members with over eight percent agreement percentage.

\section{Tool Stability:}

The stability of the tool was calculated using the Alpha Kronbach stability coefficient on the estimated stability values of the beneficiaries' questionnaire on the promotion of social peace culture among young people using community dialogue. The questionnaire was implemented with a sample of ten board members and employees and ten social workers in the study community.

B. Questionnaire with beneficiaries on realizing social peace among youth through social dialogue.

The researcher designed a questionnaire for beneficiaries on promoting peace culture among youth using social dialogue.

The tool was then presented to twelve faculty members at the Faculty of Social Work, Helwan University for review. The tool was approved by the faculty members with over eight percent agreement percentage.

\section{Tool Stability:}

The stability of the tool was calculated using the Alpha Kronbach stability coefficient on the estimated stability values of the beneficiaries' questionnaire on the promotion of social peace culture among young people using community dialogue. The questionnaire was implemented with a sample of twelve individuals in the study community.

\section{Fields:}

1- Physical field: A listing of nongovernmental organizations active in the field of social peace and applying social dialogue was made with the help of the Ministry of Social Solidarity and human rights organizations. The list contains twelve organizations, of which six organizations were excluded for lack of commitment or lack of cooperation. The research targeted the other six organizations. 
2- Human place: It is the identification of individuals forming the research target community and their demographic characteristics. The human dimension of the research is represented in:

1- Board members, staff, and social workers in the targeted organizations (100 sample).

2- A random sample chosen in light of the ideal sampling for the field research and the total number of beneficiaries (745 beneficiaries), using the following equation: $\mathrm{S}=\mathrm{X} 2 \mathrm{NP}(1-\mathrm{P}) \div\{\mathrm{d} 2(\mathrm{~N}-1)+\mathrm{X} 2 \mathrm{P}(1-\mathrm{P})\}$

\section{Statistical Analysis Methods:}

The data has been processed on computer using SPSS.V.17.0 software, the statistical package of social sciences. The following statistical methods were applied:

1- Repetitions and percentages.

2- Arithmetic mean.

\section{Results:}

1. Efforts exerted by NGOs to promote the culture of social peace:Concept of Social Peace, as identified by beneficiaries:

Increased safety among community members was ranked the highest in responses, with an arithmetic mean of 2.55 , followed by accepting opinions of others and respecting differing opinions, with an arithmetic mean of 2.36. This result coincides with the statement made by Mary Robinson, Representative for the United Nations for Human Rights, in which she clarified that social peace is a community environment where such values like acceptance for others, respecting rights, and tolerance prevail, (Ezzat, 2001, p. 152).

2. Behaviors that could be acquired through participation in the activities and programs implemented by NGOs:

'Tolerance' came in the first place, with an arithmetic mean (2.68). 'Cooperation' came in the second place (2.57), followed by 'amity' in the third place (2.53), and finally, 'justice' in the fourth place, with an arithmetic mean of (2.53).

3. Methods for learning the concepts of social peace, as identified by beneficiaries:

'Family' was ranked the highest $(87.5 \%)$, and in the fifth place "media' (55\%). These results assert the important role played by the family in social upbringing and in instilling the values of tolerance. This result coincides with the statement made by National Literacy 
Trust, which refers to the family and home environment has a strong impact on the family member's language and literacy development. (McCoy, E, Cole, J. 2011)

4. Importance of spreading the culture of social peace among all community sectors:

The first place in responses was 'strengthening the youth ability to solve problems through understanding' with a mean of (2.62). And 'strengthening youth feelings of affiliation and loyalty to their country' in the third place by arithmetic mean of (2.43). These results coincide with the organization theory in addition to making use of the theory as a tool for influencing individuals in organizations and society.

5. The Importance of peace culture in modifying the behavior of youth:

The highest rank in responses was for 'valuing differences between young people' in first place with arithmetic mean (2.48), followed by 'creating a spirit of respect for the opinion of others' in the second place with arithmetic mean (2.46). In the third place came 'contributing to realizing justice and equality' with a mean of (2.35). This means that the integration of social peace within the overall culture of the community may be translated into social indicators, which represent a behavioral framework for youth in different situations.

6. NGOs contribution to developing social peace culture among youth:

Table (1) - NGOs Contribution to Developing Peace Culture among Youth

$\mathrm{N}=120$

\begin{tabular}{|c|c|c|c|c|c|c|c|c|c|c|}
\hline \multirow{3}{*}{$\mathrm{Sr}$} & \multirow{3}{*}{$\begin{array}{l}\text { Promoting the } \\
\text { Culture of Social } \\
\text { Peace among Youth }\end{array}$} & \multicolumn{6}{|c|}{ Responses } & \multirow{3}{*}{$\mathbf{M}^{*}$} & \multirow{3}{*}{$\mathbf{S}^{* * *}$} & \multirow{3}{*}{ Rank } \\
\hline & & \multicolumn{2}{|c|}{ Yes } & \multicolumn{2}{|c|}{ No } & \multicolumn{2}{|c|}{$\begin{array}{c}\text { To some } \\
\text { extent }\end{array}$} & & & \\
\hline & & $\overline{\mathbf{K}}$ & $\%$ & $\mathbf{K}$ & $\%$ & $\overline{\bar{K}}$ & \% & & & \\
\hline 1 & $\begin{array}{l}\text { Organizes seminars } \\
\text { and conferences on } \\
\text { respecting and } \\
\text { accepting the opinion } \\
\text { of others. }\end{array}$ & 94 & 78.3 & 17 & 14.2 & 9 & 7.5 & 2.71 & 0.6 & 1 \\
\hline 2 & $\begin{array}{l}\text { Uses training experts } \\
\text { in programs targeting } \\
\text { positive coexistence }\end{array}$ & 64 & 53.3 & 39 & 32.5 & 17 & 14.2 & 2.39 & 0.73 & 2 \\
\hline
\end{tabular}




\begin{tabular}{|c|c|c|c|c|c|c|c|c|c|c|}
\hline \multirow{3}{*}{ Sr. } & \multirow{3}{*}{$\begin{array}{c}\text { Promoting the } \\
\text { Culture of Social } \\
\text { Peace among Youth }\end{array}$} & \multicolumn{6}{|c|}{ Responses } & \multirow{3}{*}{$\mathbf{M} *$} & \multirow{3}{*}{$\mathbf{S}^{* * *}$} & \multirow{3}{*}{ Rank } \\
\hline & & \multicolumn{2}{|c|}{ Yes } & \multicolumn{2}{|c|}{ No } & \multicolumn{2}{|c|}{$\begin{array}{c}\text { To some } \\
\text { extent }\end{array}$} & & & \\
\hline & & $\mathbf{K}$ & $\%$ & $\mathbf{K}$ & $\%$ & $\mathbf{K}$ & $\%$ & & & \\
\hline & $\begin{array}{l}\text { between youth and } \\
\text { community members. }\end{array}$ & & & & & & & & & \\
\hline 3 & $\begin{array}{l}\text { Presents real examples } \\
\text { of how to solve } \\
\text { problems. }\end{array}$ & 53 & 44.2 & 45 & 37.5 & 22 & 18.3 & 2.26 & 0.75 & 6 \\
\hline 4 & $\begin{array}{l}\text { Maintains } \\
\text { communication with } \\
\text { organizations. }\end{array}$ & 57 & 47.5 & 37 & 30.8 & 26 & 21.7 & 2.26 & 0.79 & 7 \\
\hline 5 & $\begin{array}{l}\text { Implements programs } \\
\text { that apply the concepts } \\
\text { of social peace culture. }\end{array}$ & 58 & 47.3 & 40 & 33.3 & 22 & 18.3 & 2.3 & 0.76 & 5 \\
\hline 6 & $\begin{array}{l}\text { Presents issues related } \\
\text { to social peace culture. }\end{array}$ & 62 & 51.7 & 42 & 35 & 16 & 13.3 & 2.38 & 0.71 & 3 \\
\hline 7 & $\begin{array}{l}\text { Organizes } \\
\text { camps. }\end{array}$ & 59 & 49.2 & 39 & 32.5 & 22 & 18.3 & 2.31 & 0.76 & 4 \\
\hline & & . & able & & & & & 2.73 & 0.45 & $\begin{array}{l}\text { high } \\
\text { level }\end{array}$ \\
\hline
\end{tabular}

* $\mathrm{M}=$ arithmetic mean $* * \mathrm{~S}=$ standard deviation

The previous table shows that 'organizing seminars and conferences on respecting and accepting the opinion of others' was ranked first with an arithmetic mean of (2.71), followed by 'using training experts in programs targeting positive coexistence between youth and community members' in the second place with a mean of (2.39). These results reflect the important role that NGOs play in developing the culture of social peace among youth.

7. Methods that NGOs use to spread the culture of social peace:

Table (2) - Methods that NGOs Use to Spread the Culture of Social Peace $\quad \mathbf{N}=120$

\begin{tabular}{|c|c|c|c|c|c|c|c|c|c|c|}
\hline \multirow{3}{*}{ Sr. } & \multirow{3}{*}{$\begin{array}{l}\text { Methods of Spreading } \\
\text { Social Peace Culture }\end{array}$} & \multicolumn{6}{|c|}{ Responses } & \multirow{3}{*}{$\mathbf{M}^{*}$} & \multirow{3}{*}{$\mathbf{S}^{* *}$} & \multirow{3}{*}{ Rank } \\
\hline & & \multicolumn{2}{|c|}{ Yes } & \multicolumn{2}{|c|}{ No } & \multicolumn{2}{|c|}{$\begin{array}{c}\text { To some } \\
\text { extent }\end{array}$} & & & \\
\hline & & $\mathbf{K}$ & $\%$ & $\mathbf{K}$ & $\%$ & $\mathbf{K}$ & $\%$ & & & \\
\hline 1 & $\begin{array}{l}\text { Exchange visits with } \\
\text { NGOs. }\end{array}$ & 74 & 61.7 & 29 & 24.2 & 17 & 14.2 & 2.48 & 0.73 & 1 \\
\hline 2 & $\begin{array}{l}\text { Seminars aiming to } \\
\text { raise awareness on } \\
\text { other cultures }\end{array}$ & 71 & 59.2 & 31 & 25.8 & 18 & 15 & 2.44 & 0.74 & 2 \\
\hline
\end{tabular}




\begin{tabular}{|c|c|c|c|c|c|c|c|c|c|c|}
\hline \multirow{3}{*}{ Sr. } & \multirow{3}{*}{$\begin{array}{l}\text { Methods of Spreading } \\
\text { Social Peace Culture }\end{array}$} & \multicolumn{6}{|c|}{ Responses } & \multirow{3}{*}{$\mathbf{M}^{*}$} & \multirow{3}{*}{$\mathbf{S} * *$} & \multirow{3}{*}{ Rank } \\
\hline & & \multicolumn{2}{|c|}{ Yes } & \multicolumn{2}{|c|}{ No } & \multicolumn{2}{|c|}{$\begin{array}{c}\text { To some } \\
\text { extent }\end{array}$} & & & \\
\hline & & $\mathbf{K}$ & $\%$ & $\mathbf{K}$ & $\%$ & $\mathbf{K}$ & $\%$ & & & \\
\hline 3 & $\begin{array}{l}\text { General reading } \\
\text { opportunities }\end{array}$ & 44 & 36.7 & 48 & 40 & 28 & 23.3 & 2.13 & 0.77 & 7 \\
\hline 4 & The internet & 64 & 53.3 & 41 & 34.2 & 15 & 12.5 & 2.41 & 0.7 & 3 \\
\hline 5 & $\begin{array}{l}\text { Dialogues and } \\
\text { discussion that help } \\
\text { build conversation } \\
\text { skills and ethics }\end{array}$ & 42 & 35 & 52 & 43.3 & 26 & 21.7 & 2.13 & 0.74 & 6 \\
\hline 6 & $\begin{array}{l}\text { Youth camps that aims } \\
\text { to build positive } \\
\text { coexistence. }\end{array}$ & 56 & 46.7 & 37 & 30.8 & 27 & 22.5 & 2.24 & 0.8 & 4 \\
\hline 7 & $\begin{array}{l}\text { Cooperation with } \\
\text { NGOs and in the field } \\
\text { of social peace }\end{array}$ & 55 & 45.8 & 34 & 28.3 & 31 & 25.8 & 2.2 & 0.83 & 5 \\
\hline 8 & $\begin{array}{l}\text { Exposure to and } \\
\text { discussing political } \\
\text { opinions of others }\end{array}$ & 41 & 34.2 & 41 & 34.2 & 38 & 31.7 & 2.03 & 0.81 & 8 \\
\hline & Tot: & VaI & able & & & & & 2.26 & 0.44 & $\begin{array}{c}\text { Med-ium } \\
\text { level }\end{array}$ \\
\hline
\end{tabular}

$* \mathrm{M}=$ arithmetic mean $* * \mathrm{~S}=$ standard deviation

The previous table shows that ' exchange visits with NGOs interested in and active in the field of social peace culture' came in the first place with an arithmetic mean of (2.48), followed by ' seminars aiming to raise awareness on other cultures' in the second place with the mean (2.44). In the third place came 'the internet', with an arithmetic mean of (2.41), and 'youth camps that aims to build positive coexistence between youth', mean (2.24), in the fourth place. The table also shows that the overall mean of the methods used by NGOs to spread the culture of social is (2.26), which is considered a medium average.

8. Role of the social workers in building a culture of social peace in society:

Table (3) - The Roles of Social Workers in Building a Culture of Social Peace in Society $\quad \mathrm{N}=82$

\begin{tabular}{|c|c|c|c|c|c|c|c|c|c|c|}
\hline \multirow{3}{*}{ Sr. } & \multirow{3}{*}{$\begin{array}{c}\text { Role of Social Worker } \\
\text { in Building a Culture } \\
\text { of Social Peace }\end{array}$} & \multicolumn{6}{|c|}{ Responses } & \multirow{3}{*}{$\mathbf{M}^{*}$} & \multirow{3}{*}{$\mathbf{S} * *$} & \multirow{3}{*}{ Rank } \\
\hline & & \multicolumn{2}{|c|}{ Yes } & \multicolumn{2}{|c|}{ No } & \multicolumn{2}{|c|}{$\begin{array}{c}\text { To some } \\
\text { extent }\end{array}$} & & & \\
\hline & & $\mathbf{K}$ & $\%$ & $K$ & $\%$ & $\overline{\mathrm{K}}$ & $\%$ & & & \\
\hline 1 & $\begin{array}{l}\text { Encouraging youth to } \\
\text { improve their }\end{array}$ & 49 & 59.8 & 17 & 20.7 & 16 & 19.5 & 2.4 & 0.8 & 2 \\
\hline
\end{tabular}




\begin{tabular}{|c|c|c|c|c|c|c|c|c|c|c|}
\hline \multirow{3}{*}{ Sr. } & \multirow{3}{*}{$\begin{array}{l}\text { Role of Social Worker } \\
\text { in Building a Culture } \\
\text { of Social Peace }\end{array}$} & \multicolumn{6}{|c|}{ Responses } & \multirow{3}{*}{$\mathbf{M}^{*}$} & \multirow{3}{*}{$\mathbf{S} * *$} & \multirow{3}{*}{ Rank } \\
\hline & & \multicolumn{2}{|c|}{ Yes } & \multicolumn{2}{|c|}{ No } & \multicolumn{2}{|c|}{$\begin{array}{c}\text { To some } \\
\text { extent }\end{array}$} & & & \\
\hline & & $\bar{K}$ & $\%$ & $\bar{K}$ & $\%$ & $\overline{\mathbf{K}}$ & $\%$ & & & \\
\hline & $\begin{array}{l}\text { capacities for applying } \\
\text { social peace culture }\end{array}$ & & & & & & & & & \\
\hline 2 & $\begin{array}{l}\text { Helping youth } \\
\text { understand the purpose } \\
\text { and objectives of the } \\
\text { NGO, that are related } \\
\text { to cultural framework } \\
\text { of social peace. }\end{array}$ & 46 & 56.1 & 23 & 28 & 13 & 15.9 & 2.4 & 0.75 & 1 \\
\hline 3 & $\begin{array}{l}\text { Introducing youth to } \\
\text { sources for building } \\
\text { understanding for the } \\
\text { concepts of social } \\
\text { peace culture }\end{array}$ & 31 & 37.8 & 36 & 43.9 & 15 & 18.3 & 2.2 & 0.7 & 8 \\
\hline 4 & $\begin{array}{l}\text { Helping youth organize } \\
\text { themselves } \\
\text { democratically }\end{array}$ & 38 & 46.3 & 24 & 29.3 & 20 & 24.4 & 2.22 & 0.82 & 7 \\
\hline 5 & $\begin{array}{l}\text { Encouraging increased } \\
\text { cooperation among } \\
\text { youth }\end{array}$ & 39 & 47.6 & 29 & 35.4 & 14 & 17.1 & 2.3 & 0.75 & 5 \\
\hline 6 & $\begin{array}{l}\text { Helping youth } \\
\text { understand and respect } \\
\text { other community } \\
\text { members }\end{array}$ & 40 & 48.8 & 30 & 36.6 & 12 & 14.6 & 2.34 & 0.72 & 3 \\
\hline 7 & $\begin{array}{l}\text { Helping youth form } \\
\text { positive relations with } \\
\text { community members }\end{array}$ & 38 & 46.3 & 31 & 37.8 & 13 & 15.9 & 2.3 & 0.73 & 4 \\
\hline 8 & $\begin{array}{l}\text { Motivating youth to } \\
\text { understand internal } \\
\text { problems through } \\
\text { positive dialogue }\end{array}$ & 40 & 48.8 & 24 & 29.3 & 22 & 2.27 & 0.8 & 6 & \\
\hline & $\begin{array}{ll}\text { Tota } \\
\end{array}$ & Var & able & & & & & 2.3 & 0.42 & $\begin{array}{c}\begin{array}{c}\text { Med-ium } \\
\text { level }\end{array} \\
\end{array}$ \\
\hline
\end{tabular}

$* \mathrm{M}=$ arithmetic mean

** $\mathrm{S}=$ standard deviation

The previous table show that 'helping youth understand the purpose and objectives of the NGO, that are related to accepting others, respecting different cultures, and solving their problems within the cultural framework of social peace' came in the first place, with an arithmetic mean of (2.4). The support that social workers provide for youth helps them identify and build relationships. They interact, and exchange their 
experiences of communication within the culture and ideology of their community.

9. Mechanisms for Using Social Dialogue in Spreading the Values of Social Peace:

Table (4) - Mechanisms for Using Social Dialogue in Spreading the Values of Social Peace: $\quad \mathrm{N}=120$

\begin{tabular}{|c|c|c|c|c|c|c|c|c|c|c|}
\hline \multirow{3}{*}{ Sr. } & \multirow{3}{*}{$\begin{array}{c}\text { Methods for } \\
\text { Developing Social } \\
\text { Peace Culture among } \\
\text { Youth } \\
\end{array}$} & \multicolumn{6}{|c|}{ Responses } & \multirow{3}{*}{ M* } & \multirow{3}{*}{$\mathbf{S}^{* *}$} & \multirow{3}{*}{ Rank } \\
\hline & & \multicolumn{2}{|c|}{ Yes } & \multicolumn{2}{|c|}{ No } & \multicolumn{2}{|c|}{$\begin{array}{c}\text { To some } \\
\text { extent }\end{array}$} & & & \\
\hline & & $\mathbf{K}$ & $\%$ & $\mathbf{K}$ & $\%$ & $\mathbf{K}$ & $\%$ & & & \\
\hline 1 & $\begin{array}{l}\text { Encouraging youth } \\
\text { Self-respect, } \\
\text { confidence and } \\
\text { respect for others }\end{array}$ & 83 & 69.2 & 19 & 15.8 & 18 & 15 & 2.54 & 0.74 & 1 \\
\hline 2 & $\begin{array}{l}\text { Promoting the value of } \\
\text { loyalty, tolerance, } \\
\text { justice, freedom, } \\
\text { belonging and } \\
\text { humanity }\end{array}$ & 71 & 59.2 & 33 & 27.5 & 16 & 13.3 & 2.46 & 0.72 & 2 \\
\hline 3 & $\begin{array}{l}\text { Supporting youth } \\
\text { cooperation and } \\
\text { participation }\end{array}$ & 70 & 58.3 & 29 & 24.2 & 21 & 17.5 & 2.41 & 0.77 & 3 \\
\hline 4 & $\begin{array}{l}\text { Youth acquiring } \\
\text { problem solving skills }\end{array}$ & 65 & 54.2 & 38 & 31.7 & 17 & 14.2 & 2.4 & 0.73 & 4 \\
\hline 5 & $\begin{array}{l}\text { Helping youth } \\
\text { understand other } \\
\text { persons and cultures } \\
\text { through participation in } \\
\text { various activities }\end{array}$ & 59 & 49.2 & 43 & 35.8 & 18 & 15 & 2.34 & 0.73 & 6 \\
\hline 6 & $\begin{array}{l}\text { Contributing to } \\
\text { building society and } \\
\text { setting aside difference, } \\
\text { thus achieving social } \\
\text { peace }\end{array}$ & 61 & 50.8 & 42 & 35 & 17 & 14.2 & 2.37 & 0.72 & 5 \\
\hline & Tot: & $v a$ & able & & & & & 2.42 & 0.43 & $\begin{array}{l}\text { high } \\
\text { level }\end{array}$ \\
\hline
\end{tabular}

* $\mathrm{M}=$ arithmetic mean

$* * \mathrm{~S}=$ standard deviation

The previous table describes the responses of beneficiaries, where the response 'encouraging youth Self-respect, confidence and respect for others' came in the first place, with an arithmetic mean of (2.54), followed by 'promoting the value of loyalty, tolerance, justice, freedom, belonging and humanity' in the second place, with the mean (2.46). These 
results coincide with the Social Control Theory, which helps understand the behavior of individuals, their acceptance or rejection of social peace culture.

10. Ranking difficulties that face NGOs in promoting the culture of social peace through social dialogue:

Table (5) - Difficulties that Face NGOs in Promoting the Culture of Social Peace through Social Dialogue $\quad \mathrm{N}=120$

\begin{tabular}{||l||l||c||r||r||}
\hline \hline Sr. & Difficulties & $\begin{array}{c}\text { Arithmetic } \\
\text { Mean }\end{array}$ & $\begin{array}{c}\text { Standard } \\
\text { Deviation }\end{array}$ & Rank \\
\hline \hline 1 & Difficulties related to society. & 2.36 & 0.44 & 1 \\
\hline \hline 2 & Difficulties related to NGOs. & 2.23 & 0.43 & 3 \\
\hline \hline 3 & Difficulties related to social workers. & 2.36 & 0.48 & 2 \\
\hline \hline & Total Variable & $\mathbf{2 . 3 2}$ & $\mathbf{0 . 3 7}$ & $\begin{array}{c}\text { Medium } \\
\text { level }\end{array}$ \\
\hline
\end{tabular}

The previous table shows the order with which the difficulties facing NGOs in promoting a culture of social peace through social dialogue were mentioned as follows:

- Difficulties related to society in the first place with an arithmetic mean of (2.36).

- Difficulties related to the social workers in the second place with an arithmetic mean of (2.36).

- Difficulties related to NGOs in the third place with an arithmetic mean of (2.23). 
The previous table provides the responses of board members and staff on the skills needed for promoting the culture of social peace among youth. The results show that 'building democratic awareness' came in the first place with an arithmetic mean of 2.64, followed by 'decision making skills' in the second place with an arithmetic mean of (2.62). The table also shows that the overall mean for the skills reached (2.52, which is considered a high mean.

Table (7) Significant Differences between Board Members and Staff of NGOs and the Social Workers Regarding Promoting the Culture of Social Peace among Youth through Social Dialogue Using T Test

\begin{tabular}{|c|c|c|c|c|c|c|c|c|}
\hline $\begin{array}{l}\mathbf{S} \\
\mathbf{r}\end{array}$ & $\begin{array}{c}\text { Variabl } \\
\text { e }\end{array}$ & $\begin{array}{l}\text { Study } \\
\text { Pop- } \\
\text { ulation }\end{array}$ & $\begin{array}{c}\text { Numbe } \\
\mathbf{r}(\mathbf{N})\end{array}$ & $\begin{array}{l}\text { Arithmet } \\
\text { ic Mean }\end{array}$ & $\begin{array}{c}\text { Standar } \\
\text { d } \\
\text { Deviatio } \\
n\end{array}$ & $\begin{array}{c}\text { Degrees } \\
\text { of } \\
\text { Freedo } \\
\text { m }\end{array}$ & $\begin{array}{c}\text { Valu } \\
\text { e of } \\
T\end{array}$ & $\begin{array}{l}\text { Signif- } \\
\text { ficance }\end{array}$ \\
\hline 1 & \multirow{2}{*}{$\begin{array}{l}\text { Role of } \\
\text { social } \\
\text { peace } \\
\text { culture in } \\
\text { achieving } \\
\text { social } \\
\text { justice } \\
\end{array}$} & $\begin{array}{l}\text { Board } \\
\text { membe } \\
\text { rs and } \\
\text { staff }\end{array}$ & 46 & 2.32 & 0.52 & \multirow[t]{2}{*}{89} & \multirow{2}{*}{$\begin{array}{c}- \\
1.40 \\
9\end{array}$} & \multirow{2}{*}{$\begin{array}{l}\text { Not } \\
\text { signif- } \\
\text { icant }\end{array}$} \\
\hline & & $\begin{array}{l}\text { Social } \\
\text { workers }\end{array}$ & 45 & 2.47 & 0.51 & & & \\
\hline \multirow[t]{2}{*}{2} & \multirow{2}{*}{$\begin{array}{l}\text { Role of } \\
\text { social } \\
\text { peace } \\
\text { culture in } \\
\text { establishin } \\
\mathrm{g} \\
\text { foundation } \\
\mathrm{s} \text { for } \\
\text { freedom }\end{array}$} & $\begin{array}{l}\text { Board } \\
\text { membe } \\
\text { rs and } \\
\text { staff }\end{array}$ & 45 & 2.47 & 0.52 & \multirow[t]{2}{*}{92} & \multirow{2}{*}{$\begin{array}{c}- \\
0.98 \\
7\end{array}$} & \multirow{2}{*}{$\begin{array}{c}\text { Not } \\
\text { signif- } \\
\text { icant }\end{array}$} \\
\hline & & $\begin{array}{l}\text { Social } \\
\text { workers }\end{array}$ & 49 & 2.58 & 0.57 & & & \\
\hline \multirow[b]{2}{*}{3} & \multirow{2}{*}{$\begin{array}{l}\text { Role of } \\
\text { social } \\
\text { peace } \\
\text { culture in } \\
\text { promotin } \\
\mathrm{g} \text { the } \\
\text { spirit of } \\
\text { tolerance } \\
\text { between } \\
\text { communit } \\
\mathrm{y} \\
\text { members } \\
\end{array}$} & $\begin{array}{l}\text { Board } \\
\text { membe } \\
\text { rs and } \\
\text { staff } \\
\end{array}$ & 46 & 2.63 & 0.51 & \multirow[b]{2}{*}{90} & \multirow[b]{2}{*}{$\begin{array}{c}- \\
0.68 \\
5\end{array}$} & \multirow[b]{2}{*}{$\begin{array}{l}\text { Not } \\
\text { signif- } \\
\text { icant }\end{array}$} \\
\hline & & $\begin{array}{l}\text { Social } \\
\text { workers }\end{array}$ & 46 & 2.56 & 0.51 & & & \\
\hline \multirow[t]{2}{*}{4} & \multirow{2}{*}{$\begin{array}{l}\text { Mechanis } \\
\text { ms for } \\
\text { using } \\
\text { social } \\
\text { dialogue in } \\
\text { spreading } \\
\text { social } \\
\text { peace } \\
\text { values }\end{array}$} & $\begin{array}{l}\text { Board } \\
\text { membe } \\
\text { rs and } \\
\text { staff } \\
\end{array}$ & 50 & 2.67 & 0.46 & \multirow[t]{2}{*}{98} & \multirow{2}{*}{$\begin{array}{c}- \\
0.67 \\
8\end{array}$} & \multirow{2}{*}{$\begin{array}{c}\text { Not } \\
\text { significa } \\
\text { nt }\end{array}$} \\
\hline & & $\begin{array}{l}\text { Social } \\
\text { workers }\end{array}$ & 50 & 2.73 & 0.43 & & & \\
\hline
\end{tabular}


* Significance at $(0.05)$

** Significance at $(0.01)$

The previous table shows that there were no statistically significant differences between board members and staff and social workers on promoting the culture of social peace among youth through social dialogue. This might mean that the responses between board members, staff, and social workers do not vary with demographic characteristics of beneficiaries (social justice, freedom, tolerance between community members, using the social dialogue as a method for spreading the values of social peace).

\section{Results Related to the First Research Question:}

What are the mechanisms used by NGOs for realizing social peace? This question can be answered through social dialogue.

Results derived from the interviews with board members and staff of NGOs were:

- Communication between community leaders was mentioned as the main mechanism used for spreading the culture and values of social peace $(84 \%)$.

- Negotiating with decision makers for making changes in youth related laws and legislations was identified as a suitable strategy for ensuring the success of social dialogue (72\%).

- Seminars were mentioned to be the most suitable media for dialogue in order to promote the values of social peace (86\%).

- Religious leaders were the main participants in social dialogue for promoting the culture of social peace $(82 \%)$.

Results derived from interviews with social workers show that communication between community leaders and scientific conferences that aim to raise community awareness on the role of youth in society are the main dialogue mechanisms for promoting social peace values.

\section{Results Related to the Second Research Question:}

What efforts are exerted by nongovernmental organizations to spread the culture of social peace? This question can be answered through the indicators: belonging and amiability.

- Results show that $88 \%$ of board members and staff used social dialogue to help youth adopt the values of social peace.

- Developing youth awareness of democracy was mentioned by $72 \%$ of board members and staff as the main skill needed for promoting the culture of social peace. 


\section{Results Related to the Third Research Question:}

What obstacles do the nongovernmental organization face in realizing social peace through social dialogue?

- The novelty of the concept of social peace was mentioned by $48 \%$ of board members and staff as the main difficulty that NGOs face.

\section{General Discussion of the Research Issues in Light of the Derived} Results:

The study responded to the research questions, identifying and describing one of most important mechanisms used by civil society organizations to spread a culture of social peace. It also described the efforts of those organizations in this area and the obstacles that they faced. Results asserted that the culture of social peace is manifested in increased safety among individuals, accepting opinions of others, and respecting differences. The results are in line with a statement made by Mary Robinson, United Nations Representative for Human Rights, explaining that social peace is a social environment where values of acceptance of others, respect for rights, and tolerance prevail,( Abdel Mawgood 2001) and where youth are given the opportunity to apply and spread the culture of peace through NGOs. The statement also affirms that such environment allows for the existence of positive and effective dialogue among young people, and for prevalence of justice and democracy within society.

This indicates the importance of participation in programs and projects implemented by NGOs aiming to develop behaviors related to the culture of social peace. Developing a culture of social peace, spreading values like tolerance, cooperation, and understanding, has been one of the trends of the revolution.

Thus, the general mean of behaviors that could be acquired through participation in NGOs' projects and programs reached (2.53), which is considered a high rate.

The results emphasized the importance of a prevailing culture of social peace in modifying behavior among youth, specifically through appreciating differences and realizing justice and equality. Therefore, integrating social peace within the culture of a society leads to its transformation into social norms that could be considered a reference framework for youth behavior in different situations. 
The contribution of NGOs to the development of a culture of social peace with a high mean reflects the important role that NGOs have in this area. NGOs implement activities to develop social peace culture among youth such as seminars and conferences addressing issues like respect and acceptance for the opinions of others. NGOs use experts and specialists who have the expertise to conduct such activities and implement training for youth while applying practically the values of social peace in those events. In addition, such activities provide space for presenting problems and ways for addressing them, as well as for communicating with other societal organizations concerned with the culture of social peace.

Concerning practitioners, the study found that ninety two percent of social workers used social dialogue to help youth acquire the values of social peace. This is confirmed through observing social workers applying social dialogue while providing youth with the opportunity to express their needs, identify their priorities, and reduce violence amongst them, which are considered some of the constructive axes in this age bracket. This is in line with the study of Jakob and Denise R( 2004), which asserted that the youth stage is considered the most important stage in strengthening peace concepts, as the social and psychological identity is formed within this age. The study also stressed the importance of youth participation in peace dialogue, where peace becomes an integral part of the youth identity, thus motivating them to work for peace.

Social workers emphasized the importance of spreading peace culture in strengthening the foundations of freedom, thus allowing grassroots voices to claim their rights freely and democratically, as seen in the 25 January revolution.

The researcher emphasizes the importance of professional and continuous training for social workers and staff of NGOs to stay informed of new trends in spreading the culture of peace in society, and discovering the talents and abilities of young people. The study of Abu El Naga Mohamed El Emary in (2007) agrees with this emphasis. The study asserts the importance of building the capacities of youth economically, politically, and social on the local, regional and international levels, thus increasing youth awareness and understanding of their own needs and problems and supporting their resolution through actual social peace practices. 
The results of the study confirm the importance of social dialogue in providing youth with the values of social peace. As a result, youth could identify their needs and form broad opinions on priority social issues through participatory practices. It is thus necessary for youth to take part in social dialogue to build an inclusive culture that allows them to build their capacities and achieve inner peace.This is consistent with Allen-Judd's (1989) study, which stressed that understanding the culture of minorities and inclusive cultures that help develop the abilities of young people is derived from achieving internal peace between individuals, organizations, and international peace.

The study results have also highlighted the skills for strengthening the culture of social peace, the most important of which is increased awareness on democracy and decision-making in this area, fostering understanding and mutual respect, and striving for coexistence and education. This is consistent with the study of Doubliet and Kaern (2007), which indicated that supporting a culture of peace is conducive to coexistence, education, dissemination of democratic values, and promoting understanding and mutual respect.

The social workers' efforts to apply social dialogue mechanism for spreading the values of social peace were manifested in communication between community leaders, conducting community awareness conferences on the role of youth in society, and formation of local committees membered by young people and their families and other community members. The purpose of such committees is to spread awareness on youth issues, address their needs, and conduct workshops to utilize the capabilities and skills of young people in the development of social values.

However, NGOs face many difficulties in promoting social peace culture using social dialogue. Some difficulties are related to society such as societal values, culture, customs and traditions, and society ideologies. Other difficulties are related to NGOs, such as financial and human resources, laws and regulations governing them, and lack of exchange of experience between organizations. Lastly, there are difficulties related to the social worker, such as weak professional training, low practice in the field, and the lack of offered training workshops for social workers. 
This requires the cooperation of all parties for instilling a culture of social peace among young people. It is thus important to build an information base for organizations related to social dialogue and to coordinate with other youth organizations within the framework of promoting a culture of social peace.

The researcher identifies several methods for spreading the culture of social peace among youth as follows:

- Engaging young people in activities that instill in them the values and objectives of peace culture.

- Effective use of media for advocacy and dissemination of information on a on peace culture involving the various stakeholders and local, regional, and national mechanisms as needed.

- Integrating peace related studies in the academic curricula.

- Conducting meetings to allow for the exchange of opinion between public persons and international leaders.

- Providing economic, financial, and media support for peace programs.

- Conducting intense and strong campaigns for spreading the culture of peace and its concepts.

\section{REFERNCES}

Abdel Latif, Rashad Ahmed, et. Al(2005)., Community management skills and practical cases, cairo, el mohandes publishing house.

Abdel Mawgood, Mohmmed Ezat,(2001) Education, peace culture, and arab issues, alexandria library, zayed center for coordination, abu dhabi.

Afify, Abdel Khalek Mohamed,( 2002) The contemporary role of social work in realizing peace and social security, paper presented at the fifteenth scientific conference titled social work and social peace, faculty of social work, helwan university.

Allen-Judd,(1989) Peace life style and peace culture, paper presented at phenajional wellness conference.

Anetzberger,Georgia J., Ishler, Karen J., Mostade, Jeffrey; Blair, Marc; (2004) Gray and Gay: A Social dialogue on the issue and concerns of older gays and lesbians.

Chapman, Thomas E.,(2007) Constructing the moral landscape through antidiscrimination law: Discourse, debate, and dialogue of sexual citizenship in Three Florida communities, Ph. D, U.S.A, The florida state university.

David Adams,Michael(1997), Peace programme,building aculture of peace, unisco,newsletter,voxxxv,no1,march,. 
Diaa for Studies and Conferences (2016-2017), Report, morocco, www.diaa.net

Doubilet, Karen,( 2007) Alice in the holy land: dramatic discoveries of arab and jewish youth in peace child israel,.

El Azab, Khairy,( 2002) The Cultural Effect of the Tourism sector in egypt And Its Role in Realizing Social Peace, research published in th fifteenth conference of the Faculty of Social work, helwan university, first volume,.

El Baalbaky, Mounir,( 1995) Resources Encyclopedia, Beirut, dar Il Ilm, ,

El Emary, Abu El Naga Mohammed,( 2007) Social dialogue and building the capacities of youth within the changes of globalization on the local and international levels, research published in the twentieth scientific conference, faculty of Social work, Helwan university, third volume,.

El Gohary, Mohammed,(1995) Social research methods, cairo, dar el maarefa el gameya.

El Saady, Amna,( 2004) Intellectual Security: Concepts, limitations, and ways of realization, paper presented in the tenth coordinative meeting for managers of research centers, criminal justice, and combating crime, saud arabia, madina, october.

El Waseet Dictionary,(1983) Third Edition, Cairo, Daerat El Maaref,

Finin, T., Joshi, A., Lolari, P., Java, A., Kale, A., \& Karandi Kar, A. (2008)The information ecology of social media and online communities. Al Magazine.

Hamada, Alaa El Sayed,(2005) Elements of security in combating intellectual extremism among youth, institute for training police officers, round number 125 ,

Harris, Lan M.; Morrison, Marylee,( 2008), Peace education, mcFarland and company, Inc. Publishers, Lefferson,.

Hott, Colleen, N., M.s,(2012). Engaging virtual communities in appreciative innovation, school of business and management, pepperdine university.

Ibrahim, Saad EI Din,( 2000) Civil society and democratic transformation in Egypt, Cairo, El Qebaa Publishing House.

Jakob,Denise R(2004), An adolescent theory of peace:astudy of adolescents conceptualization of peace.

Kerissen,(2013) https://Peacemealproject.com/category/social-peace/, , 11/ April.

Kakumani L., K. Prabhakar:(2010) Non-government organizations (PROBLEMS \& REMEDIES IN INDIA), serbian Journal of management.

Kropiuning, Ulrich; Pabst, Birgit:(2007) Strengthened self-esteem and reduced prejudices of teenage participants in a multi ethnic peace camp, germany,

Madkour, Ibrahim,( 1979) Dictionary of social sciences, egyptian book organization, Cairo. 
Marginson P.:(2006) Industrial relations at european sector level, the weak link university, warwick, england,.

McCoy, E, Cole, J. (2011). A Snapshot of local support for literacy: 2010 survey. london: national Literacy Trust, p.2.

Peppler, K.A., \& Solomon, M. (2011). Building creativity: collaborative learning and creativity in social media environments on the horizon, 19(1).

Shandar, Nabil Gamil,(2000)Management of non-governmental organizations, tripoli, lebanon, publisher not mentioned.

The Human development report(1992), New york, oxford: The undp. ,

Watfa, Aly Assad; El Shehab, Aly Gasem, School social Scient, university association for research and publishing, 2004, p.120, Citing El Horr, Abdel Aziz, Future School, Arab Education Office for Gulf Countries, El Doha, 2001, p.28.

West, Laura E,(2010) Face Work on Facebook U.S.A George Town University,.

Yehi. Miao:(2004) Determination of Legitimate Speakers of English in Discourse Social Cultural Aspects of Selected Issues, Power University. 